\title{
Regulation of granulosa cell-derived ovarian metalloproteinase inhibitor(s) by prolactin
}

\author{
S. C. Murray, S. C. Keeble, K. N. Muse and T. E. Curry, Jr \\ Division of Reproductive Endocrinology, Department of Obstetrics \& Gynecology, \\ University of Kentucky Medical Center, Lexington, KY 40536-0084, USA
}

\begin{abstract}
Increased prolactin concentrations are known to inhibit the ovarian proteolytic enzyme cascade associated with follicular rupture. It is not known whether there is also an effect of prolactin on endogenous proteinase inhibitors such as the tissue inhibitors of metalloproteinases (TIMPs). We sought to study the effect of prolactin on ovarian metalloproteinase inhibitors in cultured rat granulosa cells. Granulosa cells were cultured for $24 \mathrm{~h}$ with prolactin $\left(0-1000 \mathrm{ng} \mathrm{ml}^{-1}\right)$ in the absence or presence of LH. Metalloproteinase inhibitor activity in the conditioned culture media was measured by a colorimetric assay. Prolactin at $1000 \mathrm{ng} \mathrm{ml}^{-1}$ increased inhibitor activity by $2.86 \pm 0.63$ times. Expression of mRNA encoding TIMP-1 measured by Northern analysis increased by $2.34 \pm 0.34$ times with $100 \mathrm{ng}$ prolactin $\mathrm{ml}^{-1}$ and by $2.43 \pm 0.42$ times with $1000 \mathrm{ng}$ prolactin $\mathrm{ml}^{-1}$ compared with control cultures (no LH, no prolactin). In the presence of $\mathrm{LH}$, expression of mRNA encoding TIMP-1 and inhibitor activity increased by $2.60 \pm 0.6$ and $4.60 \pm 0.54$ times, respectively. However, no further change in mRNA expression or inhibitor activity was apparent with the addition of prolactin to LH-treated cultures. Prolactin had no effect on expression of mRNA encoding TIMP-3 in the absence or presence of $\mathrm{LH}$, although $\mathrm{LH}$ stimulated a 1.7-fold increase in mRNA encoding TIMP-3 compared with controls. Addition of prolactin had no effect on media concentrations of oestradiol or progesterone. These data demonstrate that metalloproteinase inhibitor activity increases with increasing doses of prolactin; however, when LH was added, this effect was no longer seen. With an increase in metalloproteinase inhibitor activity, tissue metalloproteinase action could be decreased, providing a possible explanation for the local inhibition on pre- and peri-ovulatory pathways by hyperprolactinaemia.
\end{abstract}

\section{Introduction}

Prolactin plays a critical role in various aspects of reproduction in many species. In addition to being crucial for lactogenesis, prolactin directly affects the menstrual cycle. Increased concentrations of prolactin disrupt normal ovulatory function, potentially leading to amenorrhoea and infertility (Bohnet $e f$ al., 1976; Kauppila et al., 1982). While there is a recognized central effect on the hypothalamic-pituitary axis, there is also evidence for a direct ovarian effect of prolactin (Demura et al., 1982; McNeilly et al., 1982). The effect on ovarian physiology is at several stages, including follicular maturation, steroidogenesis, ovulation, luteinization and corpus luteum function. Prolactin is part of the luteotropic complex in many species including rats, mice, pigs and sheep (Denamur $e t$ al., 1973), and may also be luteotrophic during the early stages of luteal formation in humans (McNatty et al., 1974).

Hyperprolactinaemia has been shown to interfere with ovulation (Lin et al., 1980; McNeilly, 1993; Yoshimura et al., 1994) and this effect cannot be overridden by increasing

Received I6 October 1995. gonadotrophin concentrations (Hamada et al., 1980; Yoshimura et al., 1991). Rabbit ovaries perfused with increasing concentrations of prolactin show a dose-dependent decrease in the percentage of follicles ovulating. On morphological examination of the ovarian surface, increased prolactin is shown to directly interfere with connective tissue breakdown of the follicular apex (Yoshimura et al., 1991, 1994). Thus, prolactin interferes with ovulation, in part, by preventing the mechanical events leading to rupture of the mature follicle.

Apical connective tissue remodelling during follicular rupture occurs through the action of proteolytic enzymes such as the matrix metalloproteinases (reviewed in Espey and Lipner, 1994). Matrix metalloproteinases are a family of enzymes involved in remodelling of the extracellular matrix, and include collagenases, gelatinases, and stromelysins. However, proteolytic activity in the extracellular space must be highly controlled for precise, localized connective tissue degradation. Proteolytic control in the extracellular space involves the metalloproteinase inhibitors, two major classes of which are distinguished: tissue derived and serum borne inhibitors (Birkedal-Hansen et al., 1993). The serum borne inhibitors include the macroglobulins, such as $\alpha_{2}$-macroglobulin, which is 
a $720 \mathrm{kDa}$ inhibitor that has the ability to inhibit a variety of proteinases as well as several growth factors (Barrett and Starkey, 1973). The tissue-derived inhibitors are referred to as tissue inhibitors of metalloproteinases (TIMPs) and comprise three distinct proteins (Matrisian, 1990; Kleiner and Stetler-Stevenson, 1993). TIMP-1, a $29 \mathrm{kDa}$ protein, binds to the active form of matrix metalloproteinases on a $1: 1$ basis. TIMP-2 (21 kDa) and TIMP-3 (23 kDa) have been shown to be differentially regulated from TIMP-1 and may act selectively on specific matrix metalloproteinases (Pavloff et al., 1992; Roswit et al., 1992; Leco et al., 1994). In addition, TIMP-1 and TIMP-2 are secreted and remain available to bind to free enzyme, whereas TIMP-3 is secreted and then predominantly bound to the extracellular matrix, further contributing to the selectivity and specificity of TIMP action (Pavloff et al., 1992; Roswit et al., 1992).

In the ovary, TIMPs are believed to act in part to control the site and extent of follicular connective tissue remodelling associated with ovulation. The effect of prolactin on expression of mRNA encoding TIMPs and inhibitor activity has not been investigated. In the present study we examined the effect of prolactin on ovarian metalloproteinase inhibitor production and activity to understand further the mechanism by which prolactin may act to disrupt follicular rupture. We specifically examined expression of mRNA encoding TIMP-I because mRNA encoding TIMP-1 is abundant in rat and human granulosa cells, is stimulated by the periovulatory LH surge, is secreted in response to hormonal stimuli, and TIMP-I-like activity is found in granulosa cell conditioned media (Rapp et al., 1990; Mann et al., 1991). We were interested in TIMP-3 because this metalloproteinase inhibitor provides an additional regulatory stop-point for metalloproteinase activity, as it is largely bound to the extracellular matrix (Pavloff et al., 1992). Differential regulation of TIMP-I and TIMP-3 has been observed (Leco et al., 1994). Furthermore, expression of mRNA encoding TIMP-3 has not been characterized in the ovary. TIMP-2 is located in the thecal cells and so was not studied (Smith et al., 1995).

\section{Materials and Methods}

Immature female Sprague-Dawley rats (Harlan SpragueDawley, Indianapolis, IN) were housed in controlled environmental conditions under the care and supervision of a licensed veterinarian. Rats were maintained on a $14 \mathrm{~h}$ light:10 h dark cycle and provided with water and rat chow ad libitum. All animal procedures for these experiments were approved by the University of Kentucky Institutional Animal Care and Use Committee. All reagents were obtained from Sigma Chemical Company (St Louis, MO) except where noted. Between 9:00 h and 10:00 h on day 23-24 of age, rats were injected with 20 iu of pregnant mares' serum gonadotrophin (PMSG) to induce follicular development and were killed $48 \mathrm{~h}$ later. Granulosa cells were obtained from preovulatory follicles as described by Mann et al. (1991). Briefly, aseptic techniques were used to remove ovaries which were cleaned of any remaining adnexa, and placed in Ham's F-12:Dulbecco's modified Eagles medium (DMEM) (GIBCO, Gaithersburg, MD) containing Hepes buffer $\left(25 \mathrm{mmol} \mathrm{l}^{-1}\right)$, gentamicin $\left(50 \mu \mathrm{g} \mathrm{ml}^{-1}\right)$, and $0.1 \%(\mathrm{w} / \mathrm{v}) \mathrm{BSA}$.
Follicles were punctured with a 26 gauge needle and granulosa cells were gently expressed and pooled. Cells were centrifuged at $600 \mathrm{~g}$ for $5 \mathrm{~min}$ and resuspended in fresh media at a

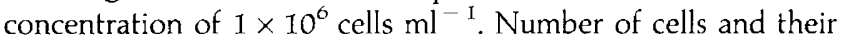
viability were determined by Trypan blue exclusion. With this method, the average yield of viable cells per ovary was $2.5 \times 10^{\circ}$. The cells were cultured in the absence or presence of $100 \mathrm{ng} \mathrm{LH} \mathrm{ml}{ }^{-1}$ with or without different concentrations of rat prolactin $\left(1,10,100,1000 \mathrm{ng} \mathrm{ml}^{-\mathrm{I}}\right.$, supplied by NIDDK, National Hormone and Pituitary Program, Baltimore, MD) for $24 \mathrm{~h}$. These concentrations of prolactin were chosen on the basis of previous published work evaluating the effect of prolactin on ovulation (Chedrese et al., 1988; Gitay Goren et al., 1989; Kransnow et al., 1990; Yoshimura et al., 1991). Ovine prolactin was also used at a dose of $1000 \mathrm{ng} \mathrm{ml}^{-1}$ to confirm the effect of rat prolactin.

After culture for $24 \mathrm{~h}$, the granulosa cells were separated from the conditioned media by centrifugation $(5 \mathrm{~min}$ at $600 \mathrm{~g}$ ). Total RNA was extracted from the granulosa cell pellets and the concentrations of mRNA encoding TIMP-I and TIMP-3 were determined by northern analysis. Inhibitor activity, progesterone, and oestradiol concentrations were determined in the conditioned media.

\section{Northern blot analysis: detection of mRNA encoding TIMP}

Total RNA was isolated from the control and prolactintreated granulosa cells $\left(3-6 \times 10^{6}\right.$ cells $)$ by extraction in guanidinium thiocyanate and centrifugation at $100000 \mathrm{~g}$ for $18 \mathrm{~h}$ over a caesium chloride gradient (Chirgwin et al., 1979; Mann et al., 1991). RNA samples (3-20 $\mu$ g per lane) underwent electrophoresis through a $1 \%$ agarose gel containing formaldehyde and were transferred to a Nytran membrane (Scleicher and Schuell, Keene, NH). cDNA probes for mouse TIMP-1, mouse TIMP-3 and rat $18 \mathrm{~S}$ were prepared by isolation of excised fragments and random primer labelling to a specific activity of $1.0-2.5 \times 10^{8}$ c.p.m. $\mu g^{-1}$ using $\left[\alpha^{-32} \mathrm{P}\right] \mathrm{dCTP}(\mathrm{New}$ England Nuclear, Boston, MA). cDNA probes were $825 \mathrm{bp}$ in length for TIMP-1, $1800 \mathrm{bp}$ for TIMP-3 and $1100 \mathrm{bp}$ for the $18 \mathrm{~S}$ (supplied by D. Edwards, Calgary, Alberta). Membranes were hybridized concomitantly with the radiolabelled cDNAs for $18 \mathrm{~h}$ at $45^{\circ} \mathrm{C}$. Membranes were washed at $42^{\circ} \mathrm{C}$ in $2 \times$ standard saline citrate (SSC) $\left(0.3 \mathrm{~mol} \mathrm{NaCl} \mathrm{l}^{-1}, 0.03 \mathrm{~mol}\right.$ citric acid $\left.\mathrm{I}^{-1}\right)+0.1 \%(\mathrm{w} / \mathrm{v}) \mathrm{SDS}$, and then washed at $65^{\circ} \mathrm{C}$ in $0.2 \times \mathrm{SSC}+0.1 \% \mathrm{SDS}$. The reaction product was visualized by autoradiography on Kodak X-AR film (Eastman Kodak, Rochester, NY). The resulting blots were analysed with an LKB Ultrascan XL laser (LKB instruments, Rockville, MD). Equality of sample loading and capillary transfer to the membrane were assessed by quantitating the blots against the $18 \mathrm{~S}$ ribosomal band to normalize the expression of mRNA encoding TIMP-1 and TIMP-3. Relative mRNA content encoding each TIMP was then expressed as arbitrary units that were calculated by setting the control $0 \mathrm{~h}$ transcript amount equal to 1.0 and expressing each other transcript amount as a fold change from that value. Control tissues included lung, liver, kidney and ovary collected from the PMSG-primed animals at the time the animals were killed for granulosa cell collection. Corpus luteum tissue was obtained from rats primed with PMSG and then by hCG $48 \mathrm{~h}$ later, and collected $24 \mathrm{~h}$ after hCG. 
Metalloproteinase inhibitor assay

Ovarian metalloproteinase inhibitor activity was measured by a colorimetric assay for metalloproteinase inhibitors as described by Mann et al. (1991). Briefly, the assay is based on the inhibition of a uterine neutral metalloproteinase by metalloproteinase inhibitors in the granulosa cell conditioned culture media. Central to this assay is the degradation of a colorimetric substrate, Azocoll (Calbiochem, La Jolla, CA) by the uterine metalloproteinase. The released red azodye is quantitated spectrophotometrically at $520 \mathrm{~nm}$. In the presence of metalloproteinase inhibitors, the activity of the uterine metalloproteinase is reduced and there is a decrease in the digestion of the Azocoll substrate and a concomitant decrease in absorbance.

The conditioned media $(100 \mu \mathrm{l})$ was mixed with the uterine neutral metalloproteinase, brought to a total volume of $400 \mu \mathrm{l}$ with assay buffer $\left(50 \mathrm{mmol}\right.$ Tris- $\mathrm{HCl} \mathrm{l}^{-1}, 10 \mathrm{mmol} \mathrm{CaCl}_{2} \mathrm{l}^{-1}$, $0.2 \mathrm{~mol} \mathrm{NaCl} 1^{-1}, 0.05 \%(\mathrm{w} / \mathrm{v})$ sodium azide, and $0.167 \%(\mathrm{v} / \mathrm{v})$ Brij 35, pH 7.5) and preincubated for $\mathrm{Ih}$ at $37^{\circ} \mathrm{C}$ to allow inhibitors present in the conditioned media to interact with the uterine metalloproteinase. Next, I mg of Azocoll suspended in $850 \mu \mathrm{l}$ of assay buffer was added to each sample and incubated for $18 \mathrm{~h}$ at $37^{\circ} \mathrm{C}$. Inhibition of the uterine metalloproteinase activity was then quantitated on a Beckman DU-64 spectrophotometer (Beckman Instruments, Fullerton, CA).

\section{Progesterone and oestradiol radioimmunoassay}

Steroid content in conditioned media from cultured granulosa cells was determined by radioimmunoassay using Coat-ACount tubes (Diagnostic Products Corp., Los Angeles, CA) as described by Jones et al. (1987). These are direct, solid phase ${ }^{125}$ I-labelled radioimmunoassay kits. A $100 \mu \mathrm{l}$ aliquot of the granulosa cell conditioned culture media (diluted 1:10) and $1.0 \mathrm{ml}$ of ${ }^{125} \mathrm{I}$-labelled steroid were added to the precoated primary antibody tubes and incubated at room temperature for $3 \mathrm{~h}$. Samples were decanted, counted in a gamma counter, and steroid concentrations determined. Progesterone and oestradiol assay sensitivities are $30 \mathrm{pg} \mathrm{ml}^{-1}$ and $8 \mathrm{pg} \mathrm{ml}^{-1}$, respectively. Intra-assay and interassay coefficients of variation are $4.7 \%$ and $9.0 \%$ for progesterone and $5.4 \%$ and $8.4 \%$ for oestradiol, respectively.

\section{Experimental design}

Each experiment was designed to test the effects of prolactin on granulosa cell derived inhibitor activity, mRNA concentrations, and steroidogenesis. The variability between different experimental replicates was normalized by expressing data as the mean fold change \pm SEM compared with the control (no LH, no prolactin). Each experimental replicate represents tissue generated from a separate group of rats collected at different time points. Differences in metalloproteinase inhibitor activity, steroid production, and mRNA abundance between prolactin treatments were tested with a one-way analysis of variance (ANOVA). Dunnett's test was used for posthoc group comparisons; $P<0.05$ was considered significant.

\section{Results}

Effect of prolactin on expression of $m R$ NA encoding TIMP-1 and TIMP-3

Northern analysis of granulosa cell expression of mRNA encoding TIMP- 1 and TIMP-3 displayed single transcripts of approximately $900 \mathrm{bp}$ and $4500 \mathrm{bp}$, respectively (Fig. 1), similar to the reported sizes of TIMP-1 and TIMP-3 (Leco et al., 1994). The expression of TIMP-1 and TIMP-3 in the positive and negative control tissues was as reported by Leco et al. (1994). The digitized values for mRNA encoding TIMP-1 $(n=3)$ and TIMP-3 $(n=2)$ were normalized against the $18 \mathrm{~S}$ ribosomal band and expressed as a fold increase in mRNA expression over the control value. The addition of 1 or $10 \mathrm{ng}$ $\mathrm{ml}^{-1}$ of prolactin to granulosa cells cultured in the absence of $\mathrm{LH}$ (100 $\mathrm{ng} \mathrm{ml}^{-1}$ ) had no significant effect on expression of mRNA encoding TIMP-1. However, the addition of prolactin to the granulosa cells resulted in a significant increase in expression of mRNA encoding TIMP- 1 at $100 \mathrm{ng}$ prolactin $\mathrm{ml}^{-1}(2.34 \pm 0.34$-fold $)$ and $1000 \mathrm{ng}$ prolactin $\mathrm{ml}^{-1}$ ( $2.43 \pm 0.42$-fold; Fig. 2). The addition of LH significantly increased expression of mRNA encoding TIMP-1 by $2.6 \pm 0.57$ times $(P<0.05)$ above cells cultured without $\mathrm{LH}$. The addition of prolactin in the presence of $\mathrm{LH}$ had a variable but nonsignificant effect on expression of mRNA encoding TIMP-1 compared with cells treated with LH alone (Fig. 2).

In contrast to expression of mRNA encoding TIMP-I, addition of prolactin to the granulosa cells had no effect on concentrations of mRNA encoding TIMP-3 in either the absence or presence of $\mathrm{LH}$. However, the addition of $\mathrm{LH}$ stimulated an increase of $1.7 \pm 0.04 \quad(P<0.05)$ times in mRNA expression compared with control cultures (data not shown).

\section{Effect of prolactin on metalloproteinase inhibitor activity}

Conditioned media from $24 \mathrm{~h}$ control cultures (no LH, no prolactin) demonstrated $9.5 \%$ inhibition of the uterine metalloproteinase. The addition of 1,10 or $100 \mathrm{ng}$ prolactin $\mathrm{ml}^{-1}$ to granulosa cells cultured in the absence of LH had no significant effect on inhibitor activity (Fig. 3). In contrast, the addition of $1000 \mathrm{ng} \mathrm{ml}^{-1}$ of either rat or ovine prolactin resulted in a 2.86 -fold increase $(P<0.05)$ in metalloproteinase inhibitor activity in the absence of LH compared with control cultures (Fig. 3). The addition of LH alone (without prolactin) to the granulosa cells resulted in a significant increase in the inhibitor activity (4.59 times the control; $P<0.05$ ), as reported by Mann et al. (1991). In the presence of LH, however, no further increase in inhibitor activity was seen with the addition of prolactin (Fig. 3).

\section{Effect of prolactin on steroidogenesis}

After $24 \mathrm{~h}$ of culture, media from control cultures contained $1.82 \mathrm{ng}$ progesterone $\mathrm{ml}^{-1}$. The addition of $\mathrm{LH}$ to the granulosa cell culture resulted in an increase of $18.5 \pm 6.9$ times $(P<0.05)$ in progesterone production over control, confirming cell viability and hormonal responsiveness. The addition of 


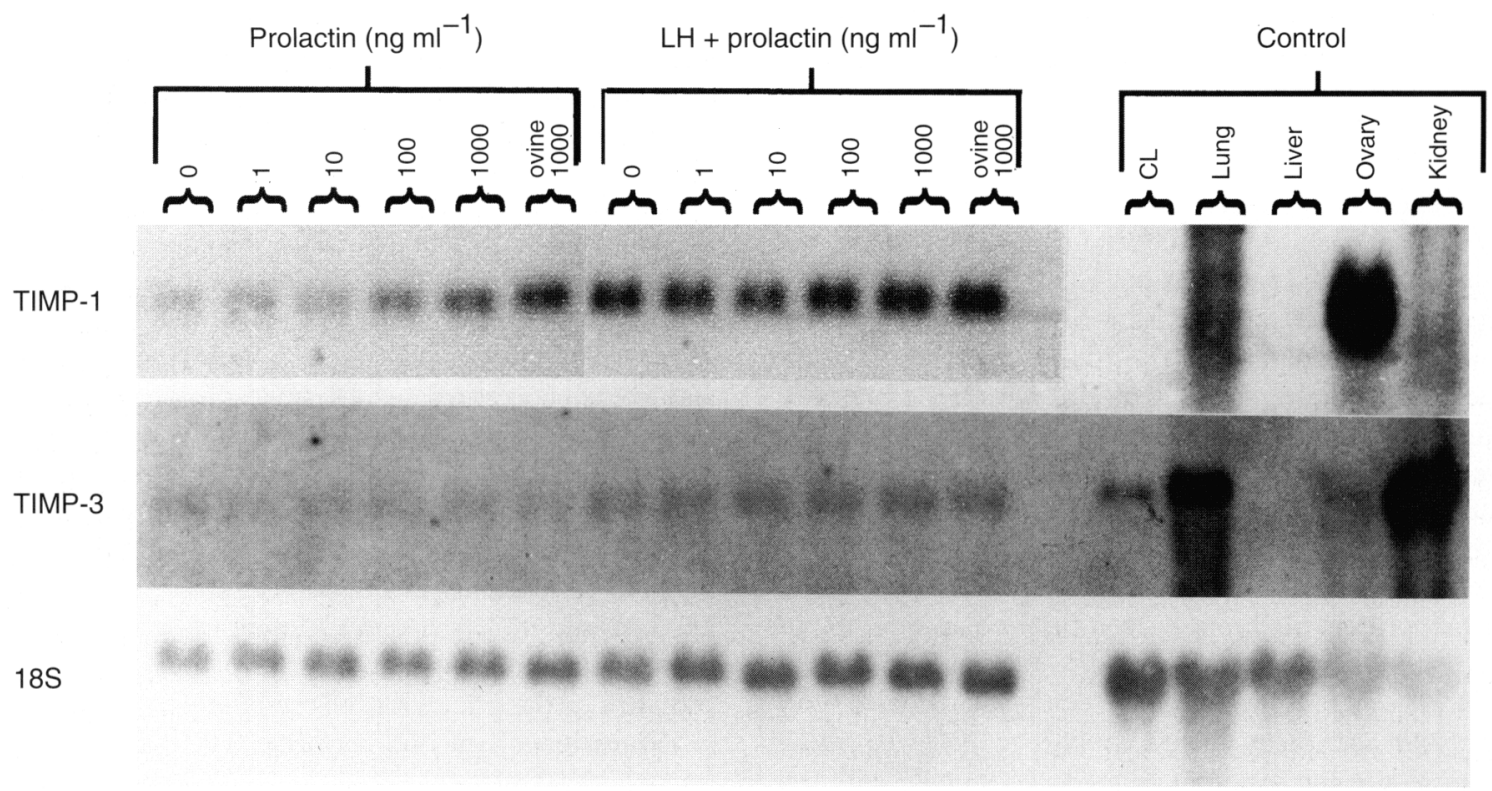

Fig. 1. Representative northern analysis of granulosa cell mRNA encoding tissue inhibitor of metalloproteinase 1 (TIMP-1) and TIMP-3. Rat granulosa cells were cultured for $24 \mathrm{~h}$ in the presence of increasing concentrations of prolactin under basal (no LH) or LH-stimulated conditions (100 ng LH ml ${ }^{-1}$ ). RNA samples were prepared from the cell pellets and hybridized with a full length mouse cDNA probe for TIMP-1 $(n=3)$ and TIMP-3 $(n=2)$. Samples were normalized to the 18 S ribosomal RNA. CL: corpus luteum.

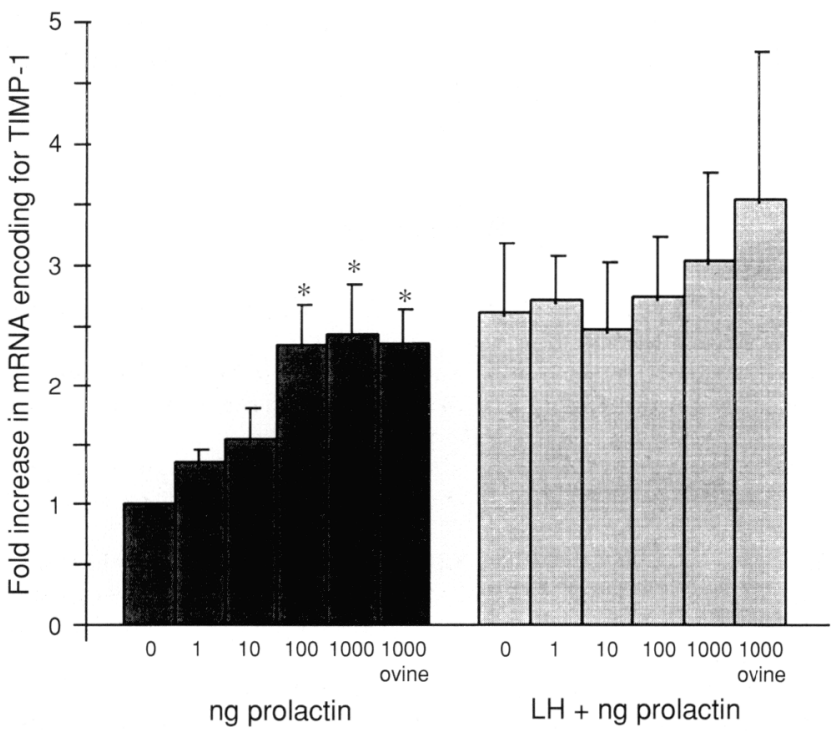

Fig. 2. Effect of prolactin on granulosa cell mRNA encoding tissue inhibitor of metalloproteinase 1 (TIMP-1). Changes in mRNA encoding TIMP-I were normalized to the $18 \mathrm{~S}$ ribosomal RNA and are expressed as the fold change versus the $24 \mathrm{~h}$ control $(0 \mathrm{ng}$ prolactin, no LH). * Significantly different $(P<0.05)$ from the $24 \mathrm{~h}$ control. Although the cultures with $\mathrm{LH}\left(100 \mathrm{ng} \mathrm{ml}^{-1}\right)$ were all significantly different from the $24 \mathrm{~h}$ control without $\mathrm{LH}(P<0.05)$, there were no significant differences within this group ( $\mathrm{LH}$ added) after prolactin treatment $(n=3)$.

prolactin in either the presence or absence of LH did not effect progesterone production by granulosa cells after culture for $24 \mathrm{~h}$.

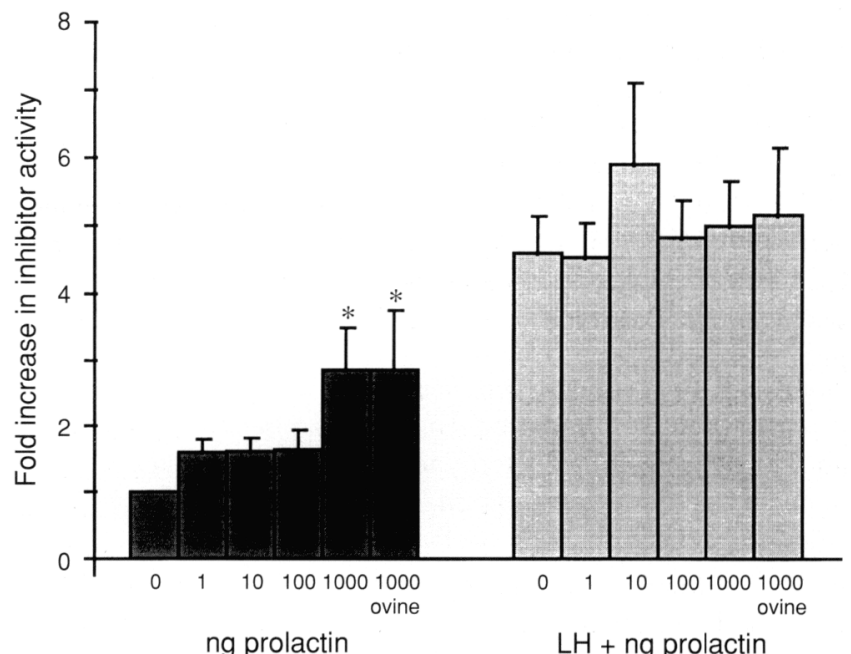

Fig. 3. Effect of prolactin on granulosa cell derived inhibitor activity. Rat granulosa cells were cultured for $24 \mathrm{~h}$ in the presence of increasing concentrations of prolactin under basal (no LH) or LH-stimulated conditions ( $100 \mathrm{ng} \mathrm{LH} \mathrm{ml}^{-1}$ ). Changes in inhibitor activity are expressed as the fold change \pm SEM versus the $24 \mathrm{~h}$ control (no prolactin, no LH). *Significantly different $(P<0.05)$ from the $24 \mathrm{~h}$ control. Although the cultures with $\mathrm{LH}$ were all significantly different from the $24 \mathrm{~h}$ control without $\mathrm{LH}(P<0.05)$, there were no significant differences within this group (LH added) after prolactin treatment ( $n=6$ in duplicate).

There was $902 \mathrm{pg}$ oestradiol $\mathrm{ml}^{-1}$ in the conditioned media from control cultures. The addition of $\mathrm{LH}$ induced an increase of 3.02 times in oestradiol production compared with the control. Similar to the findings with progesterone, the addition 
of prolactin in either the presence or absence of LH did not affect oestradiol production by granulosa cells after culture for $24 \mathrm{~h}$.

\section{Discussion}

These studies are the first demonstration that expression and activity of mRNA encoding metalloproteinase inhibitor are enhanced by prolactin. Furthermore, these findings are the first report of mRNA encoding TIMP-3 in the ovary, specifically in granulosa cells, and that LH stimulates ovarian expression of mRNA encoding TIMP-3.

The present study demonstrates that metalloproteinase inhibitor activity secreted in the conditioned culture media is enhanced by increased concentrations of prolactin. The increased activity is associated with a stimulation of cellular mRNA encoding TIMP-1, suggesting that the enhanced activity is a result of increased TIMP-I gene expression. It is unlikely that the prolactin-induced increase in inhibitor activity reflects changes in TIMP-3 because prolactin does not alter the abundance of mRNA encoding TIMP-3. Furthermore, since TIMP-3 is predominately bound to the extracellular matrix, the contribution of TIMP-3 to inhibitor activity found in the conditioned medium would be expected to be minimal. In the presence of $\mathrm{LH}$, there is a marked overall enhancement of secreted inhibitor activity in the conditioned media with no further prolactin stimulation of activity. The lack of an additive prolactin effect on metalloproteinase inhibitors in the presence of LH may be explained by $\mathrm{LH}$ induction of multiple intracellular pathways leading to metalloproteinase inhibitor production. Thus, the specific effect of prolactin is not evident in the overall LH-enhanced effect on granulosa cell metalloproteinase inhibitor activity. Our findings can be interpreted that increasing concentrations of prolactin stimulate TIMP-1 which may regulate tissue remodelling prior to and during the gonadotrophin surge.

Increased mRNA encoding TIMP-I is apparent at $100 \mathrm{ng}$ prolactin $\mathrm{ml}^{-1}$ and $1000 \mathrm{ng}$ prolactin $\mathrm{ml}^{-1}$, while increased inhibitor activity is not apparent until $1000 \mathrm{ng}$ prolactin $\mathrm{ml}^{-1}$. Follicular concentrations of prolactin have been found to be closely correlated with serum concentrations of prolactin, such that a follicular concentration of $100 \mathrm{ng} \mathrm{ml}^{-1}$ is consistent with moderate hyperprolactinaemia, while a concentration of $1000 \mathrm{ng} \mathrm{ml}^{-1}$ is consistent with marked hyperprolactinaemia (Ohwaki et al., 1992).

Physiological concentrations of prolactin do not appear to alter the role of the TIMPs in follicular remodelling. However, a moderate increase in the prolactin concentration (100 ng $\mathrm{ml}^{-1}$ ) caused an increase in mRNA encoding TIMP-I, while

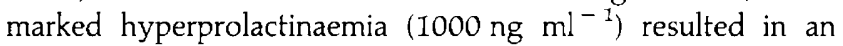
increase in inhibitor activity as well as an increase in mRNA encoding TIMP-I. The findings reported here are consistent with the observation that ovulation rates are reduced in perfused rabbit ovaries at a dose of $1000 \mathrm{ng} \mathrm{ml}^{-1}$, but not at 10 or $100 \mathrm{ng} \mathrm{ml}^{-1}$ (Yoshimura et al., 1991).

Northern analysis demonstrated that the ovary contains mRNA encoding TIMP-3, that granulosa cells are a source of TIMP-3 and that LH stimulates expression of mRNA encoding TIMP-3. The relative abundance of this inhibitor is markedly reduced compared with TIMP-1 based upon equivalent exposure times of concomitantly hybridized cDNA probes of equivalent specific activity. The role that TIMP-3 plays in ovarian function remains to be determined; however, it may play an important role in maintaining the integrity of the granulosa cell compartment during follicular rupture and as the follicle remodels to form the corpus luteum.

In summary, our results show that in a short term granulosa cell culture in vitro, increased concentrations of prolactin stimulate TIMP-I production and inhibitor activity. This effect is independent of a central effect on steroidogenesis, as progesterone and oestradiol production were unaffected. Our findings are supported by the observation that prolactin inhibits hCG-induced ovulation in a dose-dependent fashion without affecting progesterone production (Yoshimura et al., 1991). However, the present report examines only mRNA expression and activity of the metalloproteinase inhibitors and does not address the possible prolactin-induced changes in metalloproteinase action. As a working model, we would hypothesize that metalloproteinases and their associated inhibitors are precisely coordinated to regulate follicular connective tissue remodelling during the ovulatory process and that pathologically increased concentrations of prolactin could act to disrupt this coordinated balance and thus interfere with ovulation.

The authors thank $\mathrm{C}$. Moore for help with the radioimmunoassay. The authors acknowledge the gift of the mouse encoding cDNA TIMP-I and TIMP-3 and rat 18S from D. Edwards, University of Calgary. Supported by NIH HD 23195 (to T. E. Curry).

\section{References}

Barrett AJ and Starkey PM (1973) The interaction of $a_{2}$-macroglobulin molecule Biochemical Journal 133 709-724

Birkedal-Hansen H, Moore WGI, Boddenn MK, Windsor LJ, Birkedal-Hansen B, DeCarlo A and Engler JA (1993) Matrix metalloproteinases: a review Critical Reviews in Oral Biology and Medicine 4 197-250

Bohnet HG, Dahlen HG, Wuttke W and Schneider HPG (1976) Hyperprolactinaemic anovulatory syndrome Journal of Clinical Endocrinology and Metabolism 42 132-144

Chedrese P, Rajkumar K, Ly H and Murphy B (1988) Dose response of luteinized porcine granulosa cells in vitro to prolactin: dependency on pre-exposure to human chorionic gonadotropin Canadian Journal of Physiology and Pharmacology $66 \quad 1337-1343$

Chirgwin JM, Pryzbala AE, MacDonald RJ and Rutter WJ (1979) Isolation of biologically active ribonucleic acid from sources enriched in ribonuclease Biochemistry 18 5294-5299

Demura R, Ono M, Demura H, Shizume K and Oouchi H (1982) Prolactin directly inhibits basal as well as gonadotropin-stimulated secretion of progesterone and estradiol in the human ovary Journal of Clinical Endocrinology and Metabolism 54 1246-1250

Denamur R, Martinet J and Short R (1973) Pituitary control of the ovine corpus luteum Journal of Reproduction and Fertility 32 207-220

Espey LL and Lipner $\mathbf{H}$ (1994) Ovulation. In The Physiology of Reproduction pp 725-780 Eds E Knobil and JD Neill. Raven Press, New York

Gitay-Goren H, Lindendaum E and Kraiem Z (1989) Prolactin inhibits hCGstimulated steroidogenesis and cAMP accumulation, possibly by increasing phophodiesterase activity, in rat granulosa cell cultures Molecular and Cellular Endocrinology 61 69-76

Hamada Y, Schlaff S, Kobayashi Y, Santulli R, Wright K and Wallach E (1980) Inhibitory effect of prolactin on ovulation in the in-vitro perfused rabbit ovary Nature 285 161-163 
Jones HM, Vernon MW and Rush ME (1987) Androgenic modulation of periovulatory FSH release in the rat Biology of Reproduction 27 268-276

Kauppila A, Leinonen P, Vihko R and Ylostalo P (1982) Metoclopramide-induced hyperprolactinemia impairs ovarjan follicle maturation and corpus luteum function in women Journal of Clinical Endocrinology and Metabolism 54 955-960

Kleiner DE and Stetler-Stevenson WG (1993) Structural biochemistry and activation of matrix metalloproteases Current Opinion in Cell Biology 5 891-897

Kransnow JS, Hickey G and Richards J (1990) Regulation of aromatase mRNA and estradiol biosynthesis in rat ovarian granulosa and luteal cells by prolactin Molecular Endocrinology 4 13-21

Leco KJ, Khokha R, Pavloff N, Hawkes SP and Edwards DR (1994! Tissue inhibitor of metalloproteinases (TIMP-3) is an excellent matrix-associated protease with a distinctive pattern of expression in mouse cells and tissues The Journal of Biological Chemistry $2699352-9360$

Lin KC, Kawamura N, Okamura H and Mori T (1980) Inhibition of ovulation, steroidogenesis and collagenolytic activity in rabbits by sulpride-induced hyperprolactinaemia Journal of Reproduction and Fertility 83 611-618

McNatty KP, Sawers RS and McNeilly AS (1974) A possible role for prolactin in control of steroid secretion by the human Graafian follicle Nature $\mathbf{2 5 0}$ 653-655

McNeilly AS (1993) Lactational amenorrhea Endocrinology and Metabolism Clinics of North America 22 59-72

McNeilly AS, Glasier A, Jonassen J and Howie P (1982) Evidence of direct inhibition of ovarian function by prolactin Joumal of Reproduction and Fertility $65559-569$
Mann JS, Kindy MS, Edwards DR and Curry Jr TE (1991) Hormonal regulation of matrix metalloproteinase inhibitors in rat granulosa cells and ovaries Endocrinology 128 1825-1832

Matrisian LM (1990) Metalloproteinases and their inhibitors in matrix remodeling Trends in Genetics 6 12-125

Ohwaki M, Suganuma N, Seo H, Nawa A, Kikkawa F, Narita O, Matsui $\mathrm{N}$ and Tomoda $Y$ (1992) Source of prolactin in human follicular fluid Endocrinologica Japonica $39601-607$

Pavloff N, Staskus PW, Kishnani NS and Hawker SP (1992) A new inhibitor of metalloproteinases from chicken: ChIMP-a third member of the TIMP family The Journal of Biological Chemistry 26717 321-17 326

Rapp G, Freudenstein J, Klaudiny J, Mucha A, Wempe F, Zimmer M and Scheit KH (1990) Characterization of three abundant mRNAs from human ovarian granulosa cells DNA and Cell Biology 9 479-485

Roswit WT, McCourt DW, Partridge NC and Jeffery JJ (1992) Purification and sequence analysis of two rat tissue inhibitors of metalloproteinases Archives of Biochemistry and Biophysics $292402-410$

Smith GW, McCrone S, Petersen SL and Smith MF (1995) Expression of messenger ribonucleic acid encoding tissue inhibitor of metalloproteinases-2 within ovine follicles and corpora lutea Endocrinology 136 570-576

Yoshimura Y, Nakamura Y, Yamada M, Ando M, Ubukata Y, Oda T and Suzuki M (1991) Possible contribution of prolactin in the process of ovulation and oocyte maturation Hormone Research 35 (Supplement I) 22-32

Yoshimura $Y$, Jinno M, Oda T, Shiokawa S, Oshinaga A, Hanya I, Akiba M and Nakamura $Y$ (1994) Prolactin inhibits ovulation by reducing ovarian plasmin generation Biology of Reproduction $\mathbf{5 0}$ 1223-1230 